\title{
Cell population growth regulates dorsalization and caudalization during chick morphogenesis and programmed cell death in lens fibres
}

\author{
SOHAN PRABHAKAR MODAK* \\ Open Vision, Pune, India
}

\begin{abstract}
The chick embryo ectoblast was examined for a possible relationship between the state of neural competence and cell population growth. It was found that although ectoblast cells with doubling times ranging between 5 to $20 \mathrm{~h}$ exhibit neural competence, the extent of neutralization induced by the Hensen's node depends on the duration of the cell cycle; the longer the doubling time of the competent ectoblast, the stronger the induction and the greater the induced neural tissue. Neural induction in the competent ectoblast occurs in at least two steps: the first lasts for 1-2 $\mathrm{h}$ of direct contact with the inducing Hensen's node graft; a contact for another $\mathbf{2} \mathrm{h}$ with even a non-inducing post-nodal fragment is essential to consolidate neutralization. Hensen's node graft induces mitotic activity in the competent ectoblast in contact. Teratogens which inhibit cell population growth, development and blastoderm expansion in chick embryo gastrula cause concomitant caudalization of the embryonic axis. We confirm Yamada's hypothesis that dorsalization is under positive mitogenic control, whereas caudalization is controlled by a negative cell cycle regulation. Reverse transcripts of chick gastrula mRNA were cloned in pBR322. Colony hybridization with cDNA made against chicken yolk RNA showed positive clones. Thus chicken yolk contains maternal mRNAs. cDNA made against mRNA extracted from stage 10 foreheads was hybridized with RNA from stage 1 to 13 embryos, 19 day lens and egg yolk. The hybridization signal, which was low between stages 1 to 7, increased between stages 10-13 and decreased thereafter. Forehead cDNA also hybridized to yolk RNA. Thus, maternal RNA sequences are present in the early chick embryo. During lens development, epithelial cells retain proliferative activity and their progeny reaching a stationary phase join the fibre area and contribute to the growth of fibre cells. The rate of transfer from epithelium to fibre regulates the rate of programmed cell death of the non-dividing differentiated lens fibre cells.
\end{abstract}

KEY WORDS: cell population growth, neural induction, neural competence, dorsalization, caudalization

\section{Introduction}

The eukaryotic genome contains thousands of genes distributed among different coordinately expressed clusters with the members switching positions with time, and cell lineages during the development. Genetic defects, caused by mutations, lead to a variety of metabolic, physiological, structural or functional abnormalities or even lethality (Romanoff, 1972, Cohen \& Nadler, 1983). During ovogenesis, some of maternal gene products are morphogens deposited in the egg cell in form of gradients of transcripts or proteins and become functional post-fertilization in a position-, concentration- and time-dependent manner. For example, Goo- secoid interferes with the function of the primary organizer and causes cephalization (De Robertis et al., 1991), while Brachyury induces caudalization (for reviews, see Yamada, 1994, 1995; Yamada \& Modak, 1998). Defects in the expression of genes for morphogens may lead to altered patterns of their deposits and the morphogenesis of corresponding primordia. Similarly, some genes may affect the growth rates in presumptive areas of organ primordia as well as the programmed cell death (Saunders and Fallon, 1966; Modak \& Perdue, 1970). Mutations affecting the germ

Abbreviations used in this paper: HN, Hensen's node.

\footnotetext{
*Address correspondence to: Sohan Prabhakar Modak. Open Vision, 759/75 Deccan Gymkhana, Pune 411004, India. E-mail: spmodak@gmail.com
} 
line will be inherited while those in somatic cells will be restricted to the corresponding cell lineage.

Many synthetic and naturally occurring chemicals, their metabolites or by-products are teratogenic (Harbison, 1980) and are useful in studying the developmental and molecular mechanism of teratogenesis. Molecules like thalidomide that provoke increasingly defective development of the terminal segments of appendages (McBride, 1977) probably interfere in the expression of pattern defining homeobox genes. Hence, depending upon the timing of administration of a teratogen, the corresponding cells lineages and the organ primordia may be affected. In order to understand the precise mode of initiation of cell lineage-or organ primordia-specific effect of teratogens, early developing embryonic systems such as frog and chick embryos have been routinely used.

\section{Teratogens and chick development}

Early developing chick embryo is a flat disc like structure anchored at its periphery to the overlying vitelline membrane and floating on the yolk. Chick embryos have been cultured in vitro (Gallera, 1971; Modak, 2003) on plasma clot (Waddington (1932), solid agar (Spratt), with vitelline membrane stretched around a glass ring (New, 1955), or clamped between two rings (Gallera \& Nicolet, 1961) floating on albumen, explanted on filter paper supports (Olszanska \& Lassota, 1980) etc., to observe and trace early embryonic events like morphogenetic movements, axis development, neural induction, to test the teratogenicity of target chemical or physical agents, for manipulations like excision or transplantations of parts, or to study specific metabolic events using radioactive tracers. After completing her doctorate under the supervision of Prof. C.H. Waddington in Edinburgh, Dr. Leela Mulherkar joined the Department of Zoology, University of Poona in 1957 and focussed on the effect of teratogens on the critical steps in the formation of the early embryonic axis and organ primordia. Using early chick embryos, cultured in vitro, her group examined the effects of variety of metabolic inhibiters, namely, Trypan blue (Mulherkar, 1960), colchicine (Diwan, 1966), chloroacetophenone (Laxmi, 1962a \& b; Mulherkar et al., 1967), Actinomycin D (Katdare and Mulherkar, 1972), urethane (Gokhale and Mulherkar, 1980; Diwan and Mulherkar, 1980), Hydrazine hydrochloride (Telang \& Mulherkar, 1974), Chloramphenicol (Mulherkar et al., 1967; Mulherkar \& Joshi, 1969) on early morphogenesis as well as critical events of neural induction. After Prof. Mulherkar's retirement in 1977, Dr. M.V. Joshi, studied the teratogenic effect of Isonicotinic acid hydrazide (Shah and Joshi, 1980; Joshi et al.,1990) and Aflatoxin B1 (Joshi \& Joshi, 1981) on chick embryos, while Dr. S.C. Goel used as models, garden llizard embryos to study the effect of gamma radiation (Chiplonkar \& Goel (1975) and Trypan blue (Mathur \& Goel, 1976).

In his classical studies on the effect of Lithium chloride on chick embryo in vitro, Nicolet (1965) showed that the period of gastrulation is most sensitive to teratogenesis that perturbs, in a dose- and time-dependent manner, early morphogenesis and establishment of the primary embryonic axis leading to abnormal morphogenesis. Nicolet's studies $(1970,1971)$ tracing the fate of radioactive cells in the grafts of primitive node gave a clearer understanding of the positional effects of teratogens. However, little was understood about the cellular and molecular basis of teratogenesis as earlier studies depended mostly on observations of morphological changes in teratogenised embryos, but lacked the logistics and methodologies for quantitative evaluation of the cause and effect relation between normal development and that modified by such intervention.

\section{Dorsalization and caudalization}

During the formation of body axis, cells positioned along the dorso-ventral axis interact with maternal morphogens and acquire dorsal phenotype by a process termed as Dorsalization. In contrast, the Caudalization process wherein tail-specific cells are determined and positioned during the formation and growth of the tail. Yamada (1950, 1990) postulated that two principle morphogenetic events, dorsalization and caudalization, depend on growth and mitotic activity. However, the information was lacking on cell population dynamics during morphogenetic movements, including growth parameters including the time- and positiondependent changes in the size and mass of various morphological structures during the normal and abnormal development. Experiments tracing the fate of $3 \mathrm{H}$-thymidine labelled pieces, exchanged with corresponding parts, in unlabelled primitive streak stage embryos (Modak, 1966; Rosenquist, 1966; Nicolet, 1970, 71) made it possible to trace the timing-and position-specific morphogenetic movements during the early development and opened a window to investigate whether teratogens inhibit cell population growth, morphogenetic movements and cell-cell interactions thereby disturbing the temporal hierarchy for the establishment of primary embryonic axis, positioning and the formation of organ primordia. Since teratogenesis in early chick embryo invariably affects the development of the neural tube and its derivatives, Prof. Mulherkar's group studied the effect of teratogens on the inductive activity of Hensen's node, the centre of gastrulation and the neural induction. Yet, little was known on the temporal, cellular and molecular basis of embryonic induction and competence that involve interactions between effector and target cells (Gallera, 1971) leading to the processes defining and regulating cell differentiation, specifically terminal cell differentiation by the acquisition of a stable phenotype. Studies by Yamada (1977) and my group (Modak Unger-Ullmann, 1980) dealt with some of the molecular and cellular processes regulating the development and differentiation and the stability of differentiated state in the normal or regenerating lens of the eye.

\section{Cell population growth during early morphogenesis of the chick embryo}

As fertilized chicken ovocyte rolls down the oviduct, it undergoes superficial cleavages, cell multiplication and becomes a blastodisc. Solomon (1957) estimated the relative increase in cell number, DNA and RNA in the early chick embryos. Wylie (1972) used Solomon's method to estimate cell numbers in embryos during first 25 hours in freshly laid egg. Emanuelson (1965) counted cells in embryos beginning from 500 cell stage during the passage down the oviduct till the time of laying and estimated the cell multiplication rate to increase from 2 to $5 \mathrm{~h}$. McMaster \& Modak (1977) counted nuclei in embryo lysates to estimate changes in the cell population size and the amounts of DNA, RNA and proteins in chick embryos during $0 \mathrm{~h}-52 \mathrm{~h}$ or Hamburger-Hamilton (1952) stages 2 to 12 of development.

In these studies, counting isolated nuclei under phase contrast 
TABLE 1

\section{CELL POPULATION GROWTH DURING EARLY MORPHOGENESIS OF CHICK EMBRYO}

\begin{tabular}{|c|c|c|c|c|c|}
\hline Source & Region & Dev. Stages* & Visualization & Doubling Time (TG) & Reference \\
\hline \multirow[t]{2}{*}{ oviduct } & Entire & 500 cells & Light microscopy & 2 to $5,00 \mathrm{~h}$ & Emanuelsson (1965) \\
\hline & & Till laying & & & \\
\hline \multirow[t]{2}{*}{ In ovo } & Entire & 2 to 8 & Phase contrast & $6,00 \mathrm{~h}$ & McMaster\& Modak (1977) \\
\hline & “ & 9 to 13 & “ & $11,6 \mathrm{~h}$ & \\
\hline \multirow[t]{3}{*}{ In Ovo } & Entire & 4 to 9 & Fluorescence ethidiumbromide & $7,50+0,75$ & Ghatpande et al (1990) \\
\hline & & 8 to 12 & " & $12,75+2,57$ & * \\
\hline & & 4 to 12 & “ & $9,75+0,92$ & “ \\
\hline \multirow[t]{17}{*}{ In vitro } & Ares & 1 to 4 & $\mathrm{NP} 40+\mathrm{EtBr}$ & $17,7+3,70$ & Sonawane (2000) \\
\hline & Pellucida & 4 to 8 & " " & $5,20+0,50$ & “ \\
\hline & & 8 to 12 & « & $16,00+1,40$ & $"$ \\
\hline & & 1 to 12 & $“$ & $9,60+0,40$ & \\
\hline & Area Opaca & 1 to 4 & $\mathrm{NP} 40+\mathrm{EtBr}$ & $6,30+0,50$ & Sonawane (2000) \\
\hline & & 4 to 8 & " " " & $4,90+0,40$ & “ \\
\hline & & 8 to 12 & " " " & $16,70+1,90$ & “ \\
\hline & & 1 to 12 & “ “ “ & $7,60+0,20$ & \\
\hline & Are pellucida & & $\mathrm{NP} 40+\mathrm{EtBr}$ & & \\
\hline & endoblast & 1 to 4 & " " & $22,52+5,20$ & Sonawane (2000) \\
\hline & ectomesoblast & “ & “ & $13,4+2,90$ & “ \\
\hline & Area opaca & & $\mathrm{NP} 40+\mathrm{EtBr}$ & & “ \\
\hline & Yolk endoderm & 1 to 4 & " " & $5,60+0,58$ & Sonawane (2000) \\
\hline & & 1 to 10 & “ “ “ & $7,10+0,40$ & “ \\
\hline & Ectoblast & 1 to 4 & $\mathrm{NP} 40+\mathrm{EtBr}$ & $5,90+0,50$ & $"$ \\
\hline & & 1 to 10 & " " & $8,02+0,70$ & $"$ \\
\hline & Mesoblast & $3+$ to 10 & " & $3,70+0,92$ & " \\
\hline
\end{tabular}

eliminated the 10-fold overestimates, caused by the difficulty in discriminating between nuclei and large yolk granules, in studies by Solomon (1957) as well as Wylie (1972). McMaster \& Modak (1977) showed that chick embryo cell population growth is logarithmic and biphasic with doubling times $\left(\mathrm{T}_{\mathrm{G}}\right)$ of 6-7h during HamburgerHamilton (1951) stages 2 to 9 , and $12 \mathrm{~h}$ during stages 9 to 13 .

I joined the University of Poona in 1979 and began studying the effect of teratogens on growth parameters in chick embryos cultured in vitro by the double ring technique of Gallera \& Nicolet (1961). Cell nuclei were isolated from homogenates, stained with ethidium bromide were counted under fluorescence microscope (Ghatpande et al., 1990) to avoid overestimates due to false inclusion of large yolk granules that resemble nuclei under the phase contrast. Sonawane (2000) further improved on the procedure by homogenizing embryos in the presence of the non-ionic detergent NP40 to dissolve yolk granules and counting ethidium bromidestained nuclei under fluorescent microscope. McMaster \& Modak (1977) and Ghatpande et al., (1990) found that the chick embryo cell population growth is logarithmic and biphasic with doubling times $\left(T_{G}\right)$ of 6 to $7 \mathrm{~h}$ during Hamburger-Hamilton (1951) stages 2 to $9 \mathrm{~h}$, and $12 \mathrm{~h}$ during stages $9-13$. They deduced that the shift in the cell population growth parameter between stages 7 and 10 was critical as a window of transition, as it coincided with the establishment of the primary axis, folding and fusion of cell sheets, and establishment of organ primordia as well as the initiation of specific cell lineages. Results of studies on cell population growth obtained by from different authors are summarised in Table 1. Sonawane (2000) found that chick embryonic cell populations exhibit tri-phasic logarithmic growth during stages 1 to 12 . During first phase, between stages 1 and 4 , the doubling times $\left(T_{G}\right)$ are $17.7 \mathrm{~h}$ in the area pellucida and 6.3h in the area opaca. During the second phase, between stages 4 to 8 , the cell population doubling times shorten in both areas down to $5.2 \mathrm{~h}$ in the area pellucida and $4.9 \mathrm{~h}$ in the area opaca. In the third phase (st.8-12)the doubling times increase again to $16 \mathrm{~h}$ in the area pellucida and $16.7 \mathrm{~h}$ in the area opaca. From early chick embryos, surgically isolated germ layers ectoblast, mesoblast and endoblast, and the vitelline endoderm exhibit varying cell population doubling times (Table 1). Thus, the initial cell population growth occurs in the area opaca thereby driving cellular movements towards the area pellucida although the surface area covered by the area pellucida, estimated by planimetry, grows very slowly at early stages. Thereafter, both areas exhibit accelerated growth coincident with the laying down of the primitive embryonic axis. The $2^{\text {nd }}$ phase represents a window for rapid recruitment of cells leading to the consolidation of the primary embryonic axis and organ primordia in the area pellucida although, during this period, the expansion of the area opaca is much faster than the area pellucida, while the cell population doubling time is about the same in both areas, which must cause stretching of area opaca cells. Keller's group $(2000,2003)$ has suggested models to explain the biomechanics of cell shape changes, which we feel are regulated by differential cell population growth parameters. Measurements of the total blastoderm area between stages 1-10, showed (Sonawane, 2000) that the area doubling time $\left(T_{A}\right)$ is $4.9 \mathrm{~h}$ for the area opaca and $28.9 \mathrm{~h}$ for the area pellucida. Although the area occupied by the embryonic axis and organ primordia remains small during early development, the blastoderm continues to grow 5.6 times faster. Moreover, during the early development, domi- 
nated by morphogenetic movements, responsible for positioning three germ layers, the cell population grows logarithmically with an average doubling time of about $6 \mathrm{~h}$ although individual germ layers (ectoblast, mesoblast, embryonic endoblast as well as, vitelline endoblast) multiply at different rates (Table 1). This is supported by the differences in mitotic and $3 \mathrm{H}$-thymidine labelling frequencies. Therefore, the principal driving force for the morphogenetic movements appears to be the differential cell population growth that would force changes in cell shapes observed by Keller et al.(2000) depending on the extent of crowding, while those way from a non-dividing region would cause cell stretching and flattening in the area opaca.

Estimates of cell population doubling in discrete cell populations revealed (Table 1 ) that between stages 2 to 4 the embryonic endoblast invaginating through the primitive streak (Modak, 1965, $1966)$ in the area pellucida grows very slowly $\left(T_{G}=22,4 \mathrm{~h}\right)$, while the ectomesoblast in the area pellucida doubles every $13.4 \mathrm{~h}$ (Sonawane,2000). In the area opaca, the vitelline endoblast and the ectoblast (and not the extra-embryonic mesoblast) exhibit $T_{G}$ of $5.8 \mathrm{~h}$ and $5.9 \mathrm{~h}$, respectively, while the total cell population growth in the area opaca $\left(\mathrm{T}_{\mathrm{G}}=16.0 \mathrm{~h}\right)$ is, similar to that in the entire area pellucida $\left(T_{G}=16.7 \mathrm{~h}\right)$. Thus, the area opaca cell population grows mostly by mitotic activity that generates morphogenetic movements towards the area pellucida for invagination through the primitive streak to form the embryonic endoblast, the mesoblast and extraembryonic mesoblast. The pattern of incorporation of ${ }^{3} \mathrm{H}$ thymidine and the flow cytometry revealed that $40 \%$ of vitelline endoderm cells In the area opaca, are in stationary G1/G2 phases (S. Mukerjee, D. Dabir and S. P. Modak, unpublished, 1999) although these undergo stretching due to blastoderm expansion. The overall result that, during early development, the cell population growth is multiphasic has now received support from a quantitative assessment by RTPCR of changes in the number of cdc2k transcripts (A. Gore and S. P. Modak, unpublished data, 1999).

\section{Growth of chick embryo blastoderm area during early morphogenesis}

During the development in vitro for $38 \mathrm{~h}$, the blastoderm area increases in size. Changes in the area covered by the entire blastoderm (Ghatpande et al., 1990, 1991,1993; Modak et al.,1993;
Sonawane, 2000) and its parts, namely, the Area pellucida and the Area opaca (Sonawane, 2000), were measured during in vitro development 1 to $38 \mathrm{~h}$, or stages 1 to $10+$ (Table 2). Compared to the Area doubling time $\left(\mathrm{T}_{\mathrm{A}}\right)$ of $10.9 \mathrm{~h}$ for the entire blastoderm (Ghatpande et al., Modak et al., 1993) the area pellucida expands very slowly $\left(T_{A}=28.9 \mathrm{~h}\right)$ while area opaca expands $\left(T_{A}=4.9 \mathrm{~h}\right) 5-6$ times faster reaching a the area of net size nearly 100 times that of area pellucida. This suggests that for the blastoderm growth, based on the area size (Table 2) and cell numbers (Table 1), the area opaca is the principal contributordriver to the morphogenetic movements towards establishment of the primary embryonic axis in the area pellucida as well as expansion of the blastoderm by stretching and differential cell population growth at the margin of overgrowth.

\section{Positional differences in cell proliferation during early chick development}

The cell proliferative activity was estimated from a 30min pulse labelling with $3 \mathrm{H}$ thymidine and the mitotic frequency (Sonawane, 2000; Sonawane \& Modak, Ms in preparation). The Mitotic frequency was estimated at stages $2,2+, 3,3+$ and 4 from the entire blastoderm, the area pellucida and the area opaca and in the semi-circular zones surrounding the primitive streak. The zone 1 includes the tip of the primitive steak at its centre, the zones 2 to 4 are positioned successively at $0.5 \mathrm{~mm}$ distance away, while the zone 5 covers the margin of overgrowth. At stage $2+$, there is $1.5 \%$ mitotic frequency in zone I that increases gradually to reach $5 \%$ in zone $\mathrm{V}$ latter located at the area pellucida-opaca border, i.e., well away from the anterior tip of the growing primitive streak. This region delivers cells to the area pellucida for subsequent invagination as well as delimiting the presumptive neural plate. Thus, there is no evidence for high mitotic activity immediately anterior to the tip of the primitive streak. Furthermore, the newly established lineages increase in cell number rapidly with shorter $T_{G}$ in the entire area pellucida (Table 1). At stage 4 , the blastoderm area expansion is driven by localized cell proliferation at the margin of overgrowth (zone V) as evidenced by high frequency of Mitosis and $3 \mathrm{H}-\mathrm{TdR}$ labelling (New, 1959; Sonawane, 2000). Indeed, $T_{G}$ for Area opaca is $6.3 \mathrm{~h}$ at the stage 4 and decreases to $4.9 \mathrm{~h}$ probably due to the contribution of the extraembryonic mesoblast moving into this

TABLE 2

GROWTH OF BLASTODERM AREA DURING MORPHOGENESIS OF NORMAL AND TERATOGENIZED CHICK EMBRYOS IN VITRO

\begin{tabular}{|c|c|c|c|c|}
\hline Treatment & Blastoderm region & H.H.stage* & Area doubling (TA) & References \\
\hline \multirow[t]{2}{*}{ Normal } & Area opaca & 1 to 10 & $4,90+0,14$ & Sonawane (2000) \\
\hline & Area pellucida & “ & $28,90+3,30$ & Sonawane (2000) \\
\hline Normal & Entire blastoderm & 1 to 10 (38h) & $10,90+1,70$ & Modak et al., (1993) \\
\hline Retrnoic acid & “ & & & \\
\hline $10-7 \mathrm{M}$ & “ & & $14,60+5,60$ & Modak et al., (1993) \\
\hline $10-8 \mathrm{M}$ & “ & & $13,20+5,60$ & Modak et al., (1993) \\
\hline $10-9 \mathrm{M}$ & “ & & $10,8+3,90$ & Modak et al., (1993) \\
\hline Normal & Entire blastoderm & 1 to 10 (38h) & $10,92+1,81$ & Ghatpande et al., (1993) \\
\hline \multicolumn{5}{|l|}{ Trypan Blue } \\
\hline $0,08 \%$ & & & $15,70+2,90$ & Ghatpande et al., (1993) \\
\hline \multicolumn{5}{|c|}{ Lithium chloride } \\
\hline $0,025 \mathrm{M}$ & & 1 to $10(38 \mathrm{~h})$ & $18,47+6,06$ & Ghatpande et al., (1993) \\
\hline
\end{tabular}

- Hamburger Hamilton stages 
area after invaginating through the primitive streak. Thus, there is no localized high mitotic activity in the Hensen's node, and, contrary to the claims by Spratt (1966) in normal embryos, and by Stern (1979) and (MacAuley, 1993) using mitotic inhibitors, the primitive node is not a growth centre. It is very likely that they found mitotic cells near the primitive node as these were being dragged towards it due to continued morphogenetic movements during the period of treatment with mitostatic agents.

When stage 4 embryos were pulse-labelled for 30min with 3H-thymidine, similar to New (1959), the labelling frequencies were $16.5 \%$ at the area pellucida-opaca border, $39 \%$ in the middle of area opaca and $59 \%$ at the margin of overgrowth (Sonawane, 2000).

The vitelline endoderm does not participate in the formation of embryonic structures and it can be peeled off from the area opaca of stage 1-4 embryos (Modak, 1965, 1966) and examined after spreading on glass slides or in paraffin sections. At later stages, vitelline endoderm cells were recovered from the anterior V-shaped zone of area opaca, not invaded by the extraembryonic mesoblast (Sonawane, 2000). When embryos were labelled with 3 Hthymidine for up to $16 \mathrm{~h}$, the labelling frequency in the vitelline endoblast reached saturation at $6 \mathrm{~h}$, suggesting that the remaining $40 \%$ cells are in G1, G2 and/ or G0 phase (Modak, Mukherjee \& Dabir, unpublished data, 1999) and confirmed by flow cytometry profiles (Table 1). Mitotic frequency map revealed that the actual location of mitotic cells and those undergoing DNA synthesis are in form of a moving window located well anterior to the anterior tip of the primitive streak (Sonawane, 2000) and that the mitotic activity appears in form of three waves, the first located well anterior to the growing tip of the primitive streak, the second at the junction of the area pellucida and the area opaca and the third at the margin of overgrowth and these mitotic waves are preceded by gradients of cells in S phase of the cell cycle (Sonawane, 2000) (Table 3 ) and account for 13 cell population doublings.

Relationship between cell population growth, blastoderm area expansion and morphological structuring during early development of normal and teratogenised embryos

The standard tables of chick development by Hamburger and Hamilton (1951) are based on appearance of major morphological and functional characters. However these stages are not spaced at fixed intervals and cannot be used as a numerical parameter relative to cell number and blastoderm area. Therefore, Ghatpande et al. (1991) examined each embryo for 23 visible morphological characters and assigned a rank of 1 to each character. These features are 1) primitive streak, 2) Duval's crescent, 3) margin of overgrowth, 4) head process,. 5) neuro-ectoblast, 6) head fold, 7) neural plate, 8)neural fold, 9) fore gut, 10) paired heart primordia, 11) fore brain, 12) optic vesicles, 13) mid brain, 14) hind brain, 15) fused heart tubes, 16) beating heart, 17) appearance of blood islands, 18) divisions of hind brain, 19) closure of the anterior neuropore, 20) constriction of optic vesicles, 21) S-shaped heart, 22) blood islands over entire area opaca, and 23) somites with each pair given one rank order. Embryos in question are then rank ordered by adding observed rank values and compared with other quantitative parameters such as cell numbers and blastoderm area at different time points.

According to Rao and Chauhan (1971) teratogenised embryos fall under two grades of malformations, with grade I being the most severe. Based on the measurement of rank order, Ghatpande et al. (1991) expanded this classification to Grades I to IV such that the Grade I represents most malformed embryos with lowest rank order, increasing to Grade II, Grade III, and the Grade IV as the least malformed.

Analyses of $x, y, z$ plots, show the relationship between, the blastoderm area ( $x$ axis), the rank order (y axis) and cell population size ( $\mathrm{z}$ axis) of untreated control stage embryos grown in vitro for 1h, 4h, 8h, 12h, 16h and 20h. (Fig.1 A-F). During normal development these 3 parameters exhibit a direct relationship, such that higher the rank order (or, the stage of development), higher is the cell population size and larger the blastoderm area (Ghatpande, 1992). In contrast, the relationship among cell population growth, blastoderm area expansion and the rank order is disturbed during teratogenesis in a way that reveals which parameter is most 
plausible target for the teratogen. This principle also holds true for embryos treated with Trypan Blue except that the least number of embryos were found between ranks 8 and 12, corresponding to embryos reaching head fold stage (Fig. 2), suggesting that the teratogen blocks development either prior to the head fold formation or allow the escapees to develop further along with abnormal mesodermal structures. With $\mathrm{LiCl}$ the effect is even more severe (Fig. 3) with majority of embryos blocked before reaching rank 12 (Ghatpande, 1992, Ghatpande et al., 1991 and 1993). Thus, head fold formation, heralding the initiation of foregut formation, subsequent to the induction of the neural plate, is the critical event acting as a 'gate' regulating the morphogenesis of embryonic axis. One would expect that mitostatic agents would affect cell population growth while the blastoderm expansion, particularly stretching during convergent extension would be less affected. Similarly, teratogens affecting intercellular junctions, would exhibit effect on blastoderm expansion. Indeed, this methodology seems applicable to both model embryo-systems and teratogens.

It is now well established that homeotic genes are present in all living multicellular organisms investigated so far and specify segment identity by interacting with different cluster of structural and regulatory genes (Gehring, 1985; Lemaire and Kessel, 1997). Indeed, the concept that most genes are expressed independently of others now appears remote, so that most genes not only acquire temporal and positional specificity but their expression also seems to be part of co-ordinately expressed clusters. This is certainly related to, and dependent upon, the positional specificity imposed by the pattern of distribution of morphogens. For example, Yamada (1950, $1994,1995)$ proposed the model of dorsalization-caudalization for the amphibian embryos that is equally applicable to avian embryos. This model is based on two types of shifts in the positional value of responding cells; one shift is dorsalization needed to obtain neural plate cells and derivatives at anteroposterior levels, while the second shift is caudalization that is restricted posterior to the borderline marked by the anterior end of the presumptive notochord (Yamada, 1994). The dorsalization begins with the archencephalon while caudalization occurs in a gradient with apex at the posterior end. A group of genes e.g., Goosecoid and Noggin are related to dorsalization while another group represented by Brachyuri, Xho-3, Pintavallis etc., are involved in caudalization (see, for review, Yamada 1995; Yamada \& Modak, 1998). Yamada further suggested that dorsalization may depend on positive mitogenic signal while caudalization would depend on a negative mitogenic signal. There is good evidence showing that both Lithium chloride and Retinoic acid suppress cell proliferation (Table 3 ) and cause caudalization (Yamada, 1995). Indeed, a wide range of teratogens including LiCl, RA, Trypan Blue, INH, Aflatoxin, etc., studied in our laboratory, suppress of cell population growth. Conversely, one would expect that mitogenesis would favour dorsalization as evidenced by formation of the neural plate. Recent experiments (Chatterjee, Sonawane and Modak, Ms in preparation, 2019) indeed demonstrate that grafts of Hensen's node induce mitogenesis in competent ectoblast.

\section{Embryonic induction and competence in the chick embryo}

The Hensen's node grafted on a chick embryo, cultured on a plasma clot, induces neutralization in the target embryonic ectoblast that exhibits reactive capacity or competence (Waddington $1932,1952)$. Neural competence diminishes rapidly in the posterior direction (Woodside, 1937). Detailed studies by Gallera and Ivanov (1964) revealed that after full primitive streak stage, the neural competence disappears rapidly in both area pellucida and area opaca, and established that the phenomenon is similar to thatdescribed in amphibians by (Holtfreter, 1938).

Mulherkar (1958) was the first to map the inducing capacity of the primitive streak by grafting pieces of Hensen's node, and the region immediately surrounding the node, on the ectoblast in the area pellucida of primitive streak stage host embryos. Gallera (1964) showed that the inducing capacity of the graft was correlated to its state of self-differentiation. Using $3 \mathrm{H}$-thymidine labelled Hensen's nodes, Gallera and Nicolet (1969) traced the inducing cells and described the relationship between the state of their self-differentiation and the differentiation of the induced tissue (see, for review, Gallera, 1971). Nonetheless, most experimental models remained mainly descriptive despite with relatively large sample size. For example, the quantitative parameters related to the state of growth are still unknown for both inducing and competent tissues. This is relevant since the positional differences among proliferating cells in the inducer and the competent ectoblast may be relevant to the inductive response during the passage of the inductor stimulus to the ectoblast.

By early 80 s, there were few attempts to decipher basic molecular processes regulating the neural induction. Thus, chlorocetophenone (Lakshmi, 1962), colchicine (Diwan, 1966), thiol

\section{TABLE 3}

\section{EFFECT OF TERATOGENS ON CELL POPULATION GROWTH OF CHICK EMRBYOS CULTURED IN VITRO}

\begin{tabular}{|c|c|c|c|c|}
\hline Treatment & H.H.* stages & Visualization & Doubling time & Reference \\
\hline Control & 4 to $11(42 h)$ & homogenate nuclei by Phase contrast & $9.21 \mathrm{~h}$ & Joshi et al., (1991 \\
\hline $\mathrm{T} 7,2 \times 10-5 \mathrm{M}$ INH & 4 to $9(42 h)$ & as above & $12.48 \mathrm{~h}$ & “ \\
\hline INH chase $7,2 \times 105 \mathrm{M}$ P-5-PP-5-P & 4 to 11 (42h) & as above & $9.36 \mathrm{~h}$ & “ \\
\hline Control & 4 to $10(38 \mathrm{~h})$ & Homogenate nuclei + Ethidium bromide & $7.10 \mathrm{~h}$ & Modak et al., (1993) \\
\hline Retinoic acid $10-7 \mathrm{M}$ & 4 to $10(38 \mathrm{~h})$ & as above & $12.10 \mathrm{~h}$ & " \\
\hline Retinoic acid $10-8 \mathrm{M}$ & 4 to 10 (38h) & as above & $9.40 \mathrm{~h}$ & “ \\
\hline Retinoic acid $10-9 \mathrm{M}$ & 4 to 10 (38h) & as above & $8.00 \mathrm{~h}$ & “ \\
\hline Control & 4 to $10(38 \mathrm{~h})$ & Homogenate nuclei + Ethidium bromide & $7.05 \mathrm{~h}$ & Ghatpande et al., (1993) \\
\hline Lithium chloride $0,025 \mathrm{M}$ & 4 to 10 (38h) & as above & $17.80 \mathrm{~h}$ & “ \\
\hline Trypan Blue 0,075\% & 4 to 10 (38h) & as above & $9.03 \mathrm{~h}$ & " \\
\hline
\end{tabular}

- Hamburger Hamilton stages 

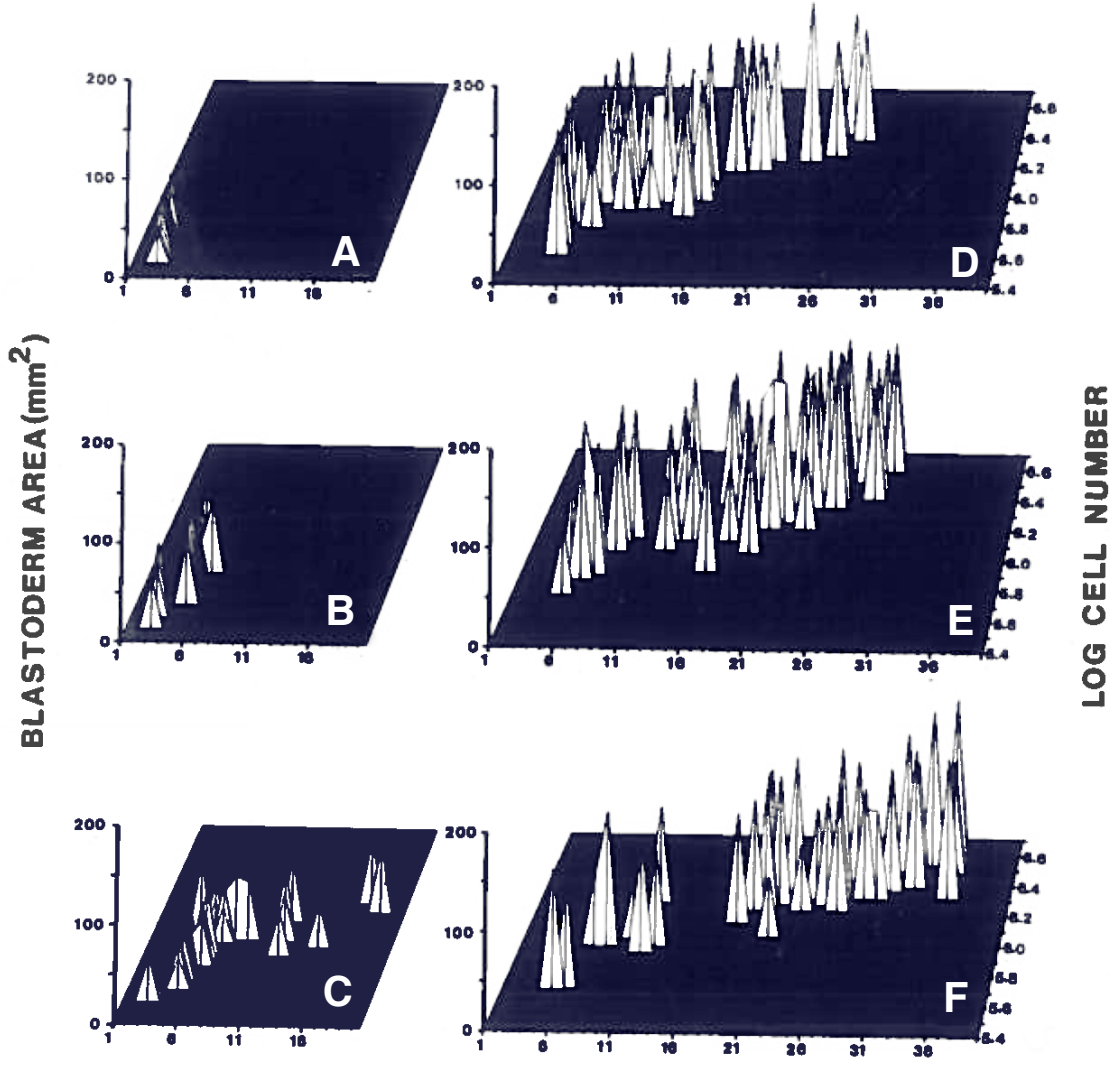

RANK

Fig. 2. Three parametric plots showing temporal changes in growth parameters of primitive streak stage chick embryos ( $18 \mathrm{~h}$ development) cultured in vitro in the presence of Trypan Blue for $\mathbf{0}$ to $\mathbf{2 0} \mathbf{~ h}$. From Ghatpande, 1992. Log cell population (Y axis); extent of development as the Rank order value (X axis); and blastoderm area $\mathrm{mm}^{2}$ ( $Z$ axis). (A) $0 h$, (B) $4 h$, (C) $8 h$, (D) $1 h$, (E) $16 h$ and (F) $20 h$.

group blockers (Lakshmi 1962, Diwan, 1966), and Actinomycin-D, an inhibitor of RNA synthesis (Gallera, 1971), were used to show that the inhibition of the inducing capacity of $\mathrm{HN}$ was reversible. It is notable that Actinomycin- $D$ inhibits the competence of reactive ectoblast, but not the inducing ability of the graft (Gallera, 1970). as the amount of RNA reaches a peak by the full primitive streak stage (McMaster and Modak, 1977), Similarly, the inhibition of induction by colchicine, known for its mitostatic action, points towards the role of cell proliferative activity in the inductor as well as recipient tissues. This is also highlighted by the changes in the type of graft differentiation by pretreatment with FSH (Sherbet and Mulherkar, 1963, 1965) and Cysteine (Waheed \&Mulherkar, 1967). While much is known about morphology and dynamic state of inducing tissues, the mechanism/s defining both temporal and positional differences in the inducing and reactive states still elude us. By $80 \mathrm{~s}$, the general mechanism and process of gene expression had become clear and much is known about the chemical and biomechanical events during cell cycle, cell migrations affecting the growth of inducer and reactive cell populations (McMaster \& Modak, 1977; Sonawane, 2000), as well as the intracellular molecular environment imprinted in form of gradients of morphogens of maternal origin (De Robertis et al., 1994, Kispert et al., 1995; Pera et al., 1999; Yamada, 1990, 1994, 1995; Yamada \& Modak,
1999, Stern, 2002; Lemaire \& Kessel, 1997; Niehrs, 1999). However. we still need to understand the nature of positional differences in the inducing and competent tissues as affected by their proliferative activity and the restriction imposed by different cell cycle phase on the period available for the transfer, interaction and accessibility of the inductor flux between inducing and competent tissues.

\section{Cell proliferative activity in chick embryos transplanted with Hensen's nodes}

The Hensen's node ( $\mathrm{HN})$, at the anterior end of the full primitive streak, contains presumptive chorda-mesoblast, presumptive somite mesoblast, presumptive neural plate and definitive endoblast (Vakaet, 1962; Modak, 1966; Nicolet, 1965, 1971; Rosenquist, 1966). Upon transplantation in the area pellucida of a host of the same age, $\mathrm{HN}$ induces a secondary axis that often fuses with the host embryonic axis making it difficult to ascertain the contribution of graft cells to the induced structure. Gallera and Ivanov (1964) grafted HNs in the area opaca where the graft and induced structures do not fuse with the host embryonic axis. The ectoblast is a contiguous pseudostratified sheet of cells and while the cells in the area pellucida move towards the primitive streak and invaginate through it, those in area opaca move in the opposite direction, which probably leads to ectoblast stretching (New, 1959; Nicolet, 1971; Sonawane, 2000; Keller, 2000). This is why the period of contactof ectoblast with the graft required to elicit induction is longer in the area opaca than in the area pellucida (Gallera, 1970). Another reason for the requirement of a longer contact in the area opaca must involve the shorter $T_{G}$ of opaca ectoblast (Sonawane, 2000).

According to the model of dorsalization-caudalization (Yamada, $1950,1994)$, induction of the nervous system is based on two types of shifts in the positional value of responding cells. The dorsalization (1950) leads to production of all types of neural plate cells and derivatives along the entire anteroposterior axis. In contrast, caudalization would occur in form of a posterior-anterior gradient of morphogens and may also influence the development of posterior brain structures. Yamada $(1950,1994,1995)$ conceptualized that the ectodermal dorsalization would depend on a positive mitogenic signal derived from the organizer. The requirement of a positive mitogenic regulation implies that the target cells must be either in a prolonged $\mathrm{G} 1$ and/or G2 phases of the cell cycle would not only bring them back in cell cycle but also positively control the rate of cell proliferation. Indeed, at the full primitive streak stage the cells in the area pellucida exhibit a longer cell doubling time $\left(T_{G}=17.7 \mathrm{~h}\right)$ compared to 6.3h in the area opaca (Sonawane, 2000; Sonawane \& Modak, Ms in preparation). Thus, neural induction should force a shift towards faster cell cycle by inducing mitogenesis in the target ectoblast. To test this, Guttikar et al., (1993) transplanted increasing number (1, 3 and 5 ) of Hensen's nodes in the area opaca of chick gastrula, but did not find any effect on the timing and rank order of developing embryos; indeed, the graft, as well 
as the induced neural tissues, differentiate synchronously. The absence of a positive change in the rank order suggested that, either there was no appreciable mitogenic signalling, or that the signal was transferred only to the cells in direct contact and not laterally. Furthermore, each graft adds about 3.5\% more cells to the host embryo, with $17.5 \%$ more cells added with 5 grafts there was no noticeable difference in the cell proliferative activity, which suggests that the grafts self-differentiate without any measurable contribution from the host.

A number of authors have examined the mitotic activity in the Hensenàs node, albeit with conflicting results with Spratt,(1966), (Stern, 1979) and MacAuley, (1993) claiming the node to exhibit high Mitotic activity. However, while Sonawane (2000), examining the ectoblast along semi-circular zones beginning immediately anterior to the Hensen's Node, found mitotic cells appearing in form of a wave originating at the border between the area pellucida and the area opaca at stage $2^{+}$and moving towards the primitive streak and, by stage 4 , forming a high mitotic zone in the presumptive neural plate where cells were present in the $\mathrm{S}$ - phase and in form of a gradient. Thus, the mitogenesis is an post-induction event, or that as cells move towards the Hensen's node and invaginate through it to form the chorda-mesoblast, one should normally see the ectoblast immediately anterior to the Hensen's node with increased mitotic activity under the influence of underlying chordamesoblast. It is now clear that mitoses appear
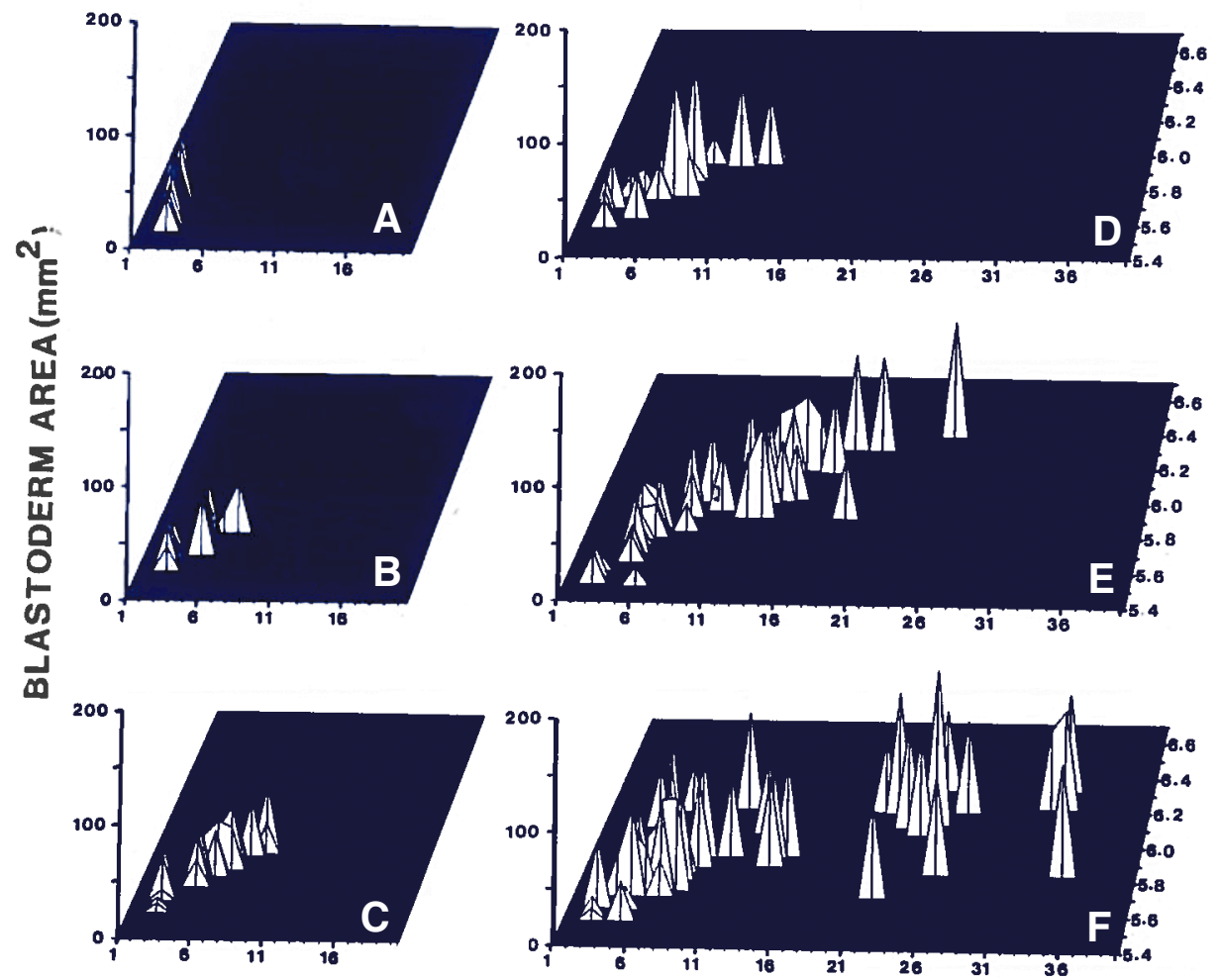

RANK

Fig. 3. Three parametric plots showing temporal changes in the growth parameters of primitive streak stage chick embryos ( $18 \mathrm{~h}$ development) cultured in vitro in the presence of lithium chloride for $\mathbf{0}$ to $\mathbf{2 0} \mathbf{~ h}$. From Ghatpande, 1992. Log cell population (Y axis), extent of development as the Rank order value (X axis), and blastoderm area in $\mathrm{mm}^{2}$ (Z axis). (A) $0 \mathrm{~h}$, (B) $4 \mathrm{~h}$, (C) $8 \mathrm{~h}$, (D) $1 \mathrm{~h}$, (E) $16 \mathrm{~h}$ and (F) $20 \mathrm{~h}$. in the ectoblast subsequent to the invagination of the presumptive chorda-mesoblast anterior to the Node and positioning under the Cauley (1993) was due to the mitotic figures, blocked by mitostatic contact between the graft and host ectoblast for 1 to $9 \mathrm{~h}$ Ms in preparation). Thus, the dorsalization depends on a positive

\section{Relationship between neural induction and the response}

In the chick embryo ectoblast in the area pellucida responds better to the neural inductive response than the area pellucida (see, Gallera and Ivanov, 1964; Gallera, 1971; Deshmukh et al., $2001,2003)$, while the neural competence is regulated temporally (Waddington, 1930, 1932; Woodside, 1937; Gallera \& Ivanov), and spatially (Gallera \& Ivanov, 1964; Gallera 1971; Leikola 1976; Storey et al., 1992; Deshmukh et al., 2001, 2003). Although the chick embryo contains a flat contiguous sheet of ectoblast that grows during development, the cell proliferative activity is not uniformly distributed (New, 1959) but present in distinct zones (Sonawane, 2000) and the ectoblast cells do not exhibit the same morphology along the radial axis (Downie, 1976). These positional and temporal differences in the properties of the ectoblast raise questions on the nature of the state of 'competence'. Confirming the observations of Gallera and Ivanov (1964), Deshmukh et al. (2001) showed that although entire ectoblast is competent to be induced stage 4 , the quality of neural induction shifts from deuterencephalic in the area pellucida to archencephalic in the area opaca and very primitive medullary structure at the margin of overgrowth with a concomitant reduction in number of induced cells, in that order. Furthermore, the frequency of mitosis and ${ }^{3} \mathrm{H}$ thymidine labelling at the centre of area pellucida increase radially in form of waves (Sonawane, 2000). Deshmukh et al., (2001) concluded that a greater neural inductive 
response requires lower proliferative activity or a longer cell cycle time most probably because, in slowly cycling cells, longer time is available in G1/G2 phases to receive and process the inductive stimulus. These results provide strong support to the notion that in dorsalization induction will be archencephalic, while during a longer cell cycle caudalization is promoted; with both processes possibly dependent on the intracellular concentration of maternal morphogens. According to Waddington (1932) neural induction is a two-step process involving 'evocation' when the neural phenotype is determined in the ectoderm and 'individuation' when the neural tube acquires regional specificity. In a sense, this proposal is not different from Yamada's dorsalization and caudalization (1950, $1993,1994)$ except that the caudalization requires interaction between already dorsalized axis with caudalizing morphogens. During neural induction the inducer and competent ectoblast requires a close contact the duration of which will determine the quality of induction (Gallera, 1971). The period of contact required is shorter $(4 \mathrm{~h})$ in the area pellucida compared to $8 \mathrm{~h}$ in the area opaca, and the reason for this difference in time of contact as well as the chronology in transfer of inductive flux were not known. Joshi-Banka etal.(2001) elegantly demonstrated that the Hensen's node kept in contact with the ectoblast for only 1-2 hours did not elicit neural induction, but, after initial contact, its replacement by a non-inducing post-nodal fragment did promote neural induction. Furthermore, if $\mathrm{HN}$ is replaced after $3-4 \mathrm{~h}$ contact by post-nodal piece the neural induction was archencephalic. Thus, the neural induction indeed occurs in at least two-steps.

Acomparison reveals that Waddington's evocation-individualtion model for induction (1932), Yamada's dorsalization-caudalization model (1950, 1990, 1994, 1995) and Nieuwkoop's (1952) activationtransformation model overlap considerably and are practically interchangeable, except for the absence of the role of morphogenes in Waddington's model. In Yamada's model dorsalization evokes a positive mitogenic response while caudalization is regulated by a negative cell cycle control. Indeed transplantation of increasing of post-nodal fragments (posterior mesoderm) in the chick gastrula caudalizes the host axis and inhibits cell population growth (Joshi'Banka et al.,2002) and mimic the effect of teratogens like isonicotinic acid hydrazide (Joshi et al., 1990), Trypan blue and LiCl (Ghatpande et al., 1993), and Retinoic acid (Modak et al., 1993). Deshmukh et al. (2003) examined whether the cell proliferative activity is correlated with the amount and quality of neural tissue induced at different positions as well as with different duration for contact with the inducing Hensen's node. They placed the Grafts at (1) the junction between the area pellucida and area opaca, (2) midway in the area opaca, and (3) at the margin of overgrowth, to find that the optimum period of contact is $4 \mathrm{~h}$ at area pellucidaopaca margin, $9 \mathrm{~h}$ in the middle of area opaca confirming earlier observations (Gallera, 1971). Dehsmukh et al. (2003) also found that the ectoblast at the margin of overgrowth is competent but requires 9-20h to elicit neural induction. Furthermore, the number of neural cells and volume of the induced were somewhat the same till midway of area opaca, but decreased at the margin of overgrowth and suggested that the duration of cell cycle is inversely proportion to the quality and quantity of the induced tissue (Deshmukh et al., 2003). Furthermore, as the ectoblast in the area pellucida with its long doubling time $\left(T_{G}=18 \mathrm{~h}\right)$ reacts best to the stimulus from $H N$, they concluded that with longer doubling time cells are accessible to the inductor flux for a longer duration in contrast to shorter dou- bling time in the area opaca and the margin of overgrowth and suggested that, at the margin of overgrowth, in cells multiplying with a short doubling time, the inductor stimulus-substance, flowing across during the period of contact, must have been preserved over at least two cell cycles. Deshmukh et al., (2003) further postulated a two phase model with onset of induction during the first phase and inhibition of cell proliferation during the second phase, the latter involving a conversion of the archencephalon into the deuterencephalon dependent on the convergent extension that directs morphogenetic cell movements dependent on the direction of cell-cell intercalation (see, for review, Yamada and Modak, 1998).

A controlled treatment with teratogens in vitro of chick embryos quantitatively inhibits cell population growth, area expansion and sequential morphogenesis of specific morphological traits (see above). The resultant negative cell cycle control results in caudalization with a concomitant suppression of dorsal features supporting Yamada's hypothesis $(1950,1994,1995)$. One of the effector in caudalization is postulated to be the posterior mesoderm. JoshiBanka et al. (2002) examined this issue by comparing the effect of 1 to 8 post-nodal pieces transplanted at the anterior margin of area pellucida, to the grafts of equivalent number of Hensen's nodes at the same location. Embryos with PN grafts were cultured for 20 hours and assessed, at the beginning $\left(\mathrm{t}_{0}\right)$, and at the end $\left(t_{20}\right)$, of the experiment, for total cell numbers, blastoderm area and rank order as described by Ghatpande et al. (1991, 1993). It was found that grafting increasing number of PNs that primarily contain posterior mesoblast, resulted in caudalization similar to that after treatment with teratogens and also expressed brachyuri (Joshi-Banka et al., 2002). Furthermore, ${ }^{3}$ Hthymidine labelled cells from PN grafts exhibited convergent extension and formation of new primitive streak surrounded by area vasculosa, unlike those from HN grafts. When an experimental manipulation affects many parameters, statistical analyses by Multiple logistic regression (MLR) reveal the identity of the most critical parameter, as well as the order of importance of the remainder. With such analyses of 13 measurable parameters, it was found (Joshi-Banka et al., 2002) that, with both PN and HN grafts, in the hierarchical order of importance stood with (1) cell population size for both HN and PN grafts, while (2) length of the head was decreased with PN grafts, in contrast to the blastoderm area and rank value with $\mathrm{HN}$ grafts. Thus, the posterior mesoderm exerts negative cell cycle control and caudalizes the host axis.

These studies quantitatively demonstrate that teratogens, Lithium chloride, Trypan blue, Retinoic acid, Isonicotinic acid hydrazide (Joshi et al., 1991; Ghatpande et al., 1991, 1993; Modak et al.,1993) caudalize the embryo by mimicking the effect of grafts of posterior mesoderm (Joshi-Banka et al., 2002) and in contrast. to effect of grafts of Hensen's nodes that initially exhibit positive mitogenesis and induce archencephalic structures which then convert to deuterncephalic with longer contact with the inducer (Joshi et al.,2003). The preferred model that fits the entire set of studies on early chick development described so far is CaudalizationDorsalization model of Yamada (1950, 1994, 1995), which hardly differs from those by Waddintgon (1932) and Nieuwkoop (1950) when one considers the role of maternal determinants distributed in form of gradients of morphogens (Rogulja and Irvine, 2005) that confer distinct positional identity to each cell and it progeny either of which may be displaced through temporally and spatially ordered morphogenetic movements, establishing with new neighbours 
and interactions culminating in establishment of the rudimentary embryonic axis and its derivatives under the regulatory control of homeobox genes (LeMaire \& Kessel, 1997) leading to the cell type specificity and acquisition of the positional identity as well as specific structural and functional phenotypes through terminal cell differentiation while still maintaining aside a group of founder cells that participate in homeostasis.

\section{Cloning cytoplasmic mRNA from primitive streak stage chick embryo and stage 10 forebrain and their distribution during development}

Cytoplasmic polyadenylated mRNA, isolated from full primitive streak stage chick embryos, was reverse transcribed and inserted into pBR322 plasmid to transform E.coli. to make a gastrula cDNA library (R. Ramakrishnan, 1988). A similar cDNA library was made from st.10 forebrain mRNA (Charu Goel, 1987). Bacterial colonies, transferred to Nylon membranes, were successively hybridized with 32P-cDNA against st.1, 4, 10, st. 10 brain and 19d chick lens mRNA. RNA was also purified from the yolk of unfertilized egg. Bacterial colonies transferred to the nylon filter membranes were hybridized with 32P-cDNA reverse transcripts of yolk mRNA, which gave some of the most intensely positive colonies showing that chicken yolk contains stored maternal mRNA. When RNA from developmental stages $1,4,7,10,13$, yolk and 19 day lens were slotblotted on Biodyne and hybridized with labelled stage 10 forehead cDNA, the signal decreased from st. 1 to 7 and then increased dramatically at st. 10 to decrease at st. 13; both yolk and lens exhibit strong signals (C. Goel, M.Phil. dissertation, 1987). When the target colonies on the same nylon membrane were successively hybridized with radioactive cDNA probes against different developmental stages, the gradient of signal intensity was similar among the group of chronologically ordered stages (Ramesh Ramakrishnan,1988). Hybridization of ${ }^{32}$ P.labeled GT, clone

14/1 revealed the lowest signal at st.1, which then increased to reach the highest for stage 10 RNA and decreased again by stage 13. (R. Ramakrishnan, 1988). This supports the observation that, with antibodies to 2.5s Nerve Growth Factor (NGF) the strongly NGF+ve cells appear first in the lumen of st.10 brain (Bhargava \& Modak, 2002). Indeed, during development, NGF is localised to the surface of invaginated mesoblast and occupies cytoplasmic location in the definitive endoblast. At head fold stage embryonic ectoderm shows strong reaction till the limit of presumptive neural crest region while the medullary plate is negative. Thus NGF does not seem to be involved in neural differentiation. It is only after the fusion of neural folds and formation of the neural tube that NGF positive cells become detectable at the anterior neuropore, roof of the forebrain, midbrain and hindbrain and the outer extremity of the optic vesicle and at the point of fusion of the neural tube. (Bhargava and Modak, 2002).

\section{Terminal lens cell differentiation}

During early morphogenesis, tissue-specific cell lines become established. Initially pluripotent, the progeny becomes increasingly committed to the expression of increasingly restricted number of specialized or differentiated phenotypes. Implicit in this process is a progressive loss of potential for tissue metaplasia, or the ability, howsoever restricted, yet germ-line specific, to be reprogrammed to express another/different phenotype (Modak \& Unger-Ullmann, 1980) as exemplified by the dorsal iris of lentectomised newts in which nondividing differentiated melanocytes lose melanin, re-enter the cell cycle and redifferentiate into lens fibre cells (Yamada, 1977). In any adult organism, most cells with specialized phenotypes are terminally differentiated and never divide again, while a few do retain the division potential, as do fibroblasts, chondrocytes etc, and can re-enter the cell cycle, but their progeny expresses the same phenotype. Terminally differentiated cells never divideagain, express a finite life-span and their loss is compensated through a pool of 'blast' cells. In a few cases, terminally differentiated cells maintain a transcriptionally active genome (e.g.neurons), some, like avian erythrocytes retain a transcriptionally inactive genome and non-dividing state but can be reactivated after fusion with other cells, and, finally those which lose their genome completely while maintaining a stable differentiated state e,g., lens fibers.(see, for review, Modak \& Unger-Ullmann, 1980).

It is known that the optic vesicle-induced, head ectodermal cells form the placode that invaginates to form a lens vesicle. Progressively, the cells from the inner hemisphere of the lens vesicle stop dividing (Modak et al., 1968) and elongate as lens fibres, exhibit active RNA synthesis (Modak \& Persons, 1970) and express lens specific crystallins (Yamada, 1977; Piatigorsky, 1980). As the developing lens grows, the oldest fibre cells located at the centre of the fibre area undergo programmed cell death in situ, nuclei undergo pycnosis and lose DNA via single strand breaks in DNA (Modak \& Perdue1970, Modak et al., 1969, Modak and Bollum, 1971, 1973) leading to the breakdown of chromatin monoand oligonucleosomal fragments (Appleby and Modak, 1977; Modak \& Beard, 1980) along with substantial loss of histone H1-I (Unger-Ullmann \& Modak, 1979). Meanwhile, lens epithelial cells continue to multiply and participate in the growth in cell number of both epithelium and lens fibre regions (Persons \& Modak, 1970). Furthermore, as older lens fibre cell nuclei disappear, immediately peripheral fibre cell nuclei undergo pycnosis, fragment and disappear. Thus, developing lens fibre cells exhibit a time-[specific and position-specific nuclear loss leaving behind intact non-nucleate cells, full of lens proteins. This phenomenon is a classic example of programmed cell death, euphemistically called as apoptosis.

\section{Modelling cell population turnover and programmed cell death during lens development}

Chick embryonic lens has a radial symmetry and contains nucleated epithelial and concentrically arranged fibre cell populations, with oldest along the optical axis, distributed in regions of different geometrical shapes. The work on chick lens development and differentiation started in 1968-69 in Yamada's group at the Oak Ridge, continued at the Swiss Institute of Experimental cancer research, Lausanne (1970-77) and completed at the University of Poona. From serial section of developing chick lenses, number of nuclei were counted from different regions of the lens epithelium, the annular pad, peripheral, middle and central lens fibres, corrected for their diameters and section thickness (Modak et al.,1973). The areas occupied by different lens regions were also measured and nuclear counts and volumes were computed for the entire lens and different parts as above. It showed that the cell population growth in lens epithelium and lens fibres are closely coordinated and probably controlled by epithelial cells.(Modak et al., 1976). 
Sonawane et al.,1999) found that epithelial cells representing the growth compartment, the intermediate region, the annular pad, normal nucleated fibres as well as the entire lens exhibit logistic growth, beginning with an exponential growth and then reaching a steady state. However, this model could not estimate the size of the non-nucleated cell population and inter-compartmental transfer rates. Finally, Sonawane, (2000) developed a compartmental model) to estimate the cell transfer rates among physically linked lens compartments showing that epithelial cell proliferation, accumulation of proto-differentiated fibres in the annular pad, differentiation and programmed nuclear death (apoptosis) events and loss in central fibres occur in repetitive synchronous bursts. Epithelial cell proliferation and cell transfer rates through the annular pad regulate apoptosis.(Sonawane, 2000; Sonawane and Modak MS in preparation).

\section{Immunochemical characterization and quantitative dis- tribution of crystallins in differentiating lens epithelium and both nucleated and non-nucleated fibre cells}

Terminally differentiated lens cells exhibit as tissue-specific biochemical phenotype with Crystallins $\alpha, \beta, \delta$ or $\gamma$, synthesised using long-lived stable mRNA templates (Yamada, 1977; Piatigorsky, 1980; Pal and Modak, 1984). Among these, $\alpha$ and $\beta$ crystallins are present in all lens cells, while lens fibres of birds and reptiles contain $\delta$ crystallins, in contrast to fishes, amphibians and mammals that contain $\gamma$ crystallins. Then existing studies compared the location and type of these proteins in the epithelium and fibre areas (Zwaan \& Ikeda, 1968; Brahma \& van der Starre, 1976; Piatigorsky, 1980; Bagchi et al., 1982). However, as both lens epithelium and fibres contain discrete cell populations in terms of their position in the cell cycle as well as stage of differentiation, positional differences in types and amounts of different crystallins had not been quantified. Pal and Modak (1984) made antibodies to total water soluble lens crystallins and purified delta crystalline and used these to quantify different crystalline species by 2 dimensional antigen-antibody crossed immuneelectrophoresis, rocket IE, IEF-immunoblotting using antibodies to total lens protein from 19 day chick embryonic lens and 6-month-old chicken lens as well as purified delta crystalline. The adult lens protein consists of $19 \% \alpha, 67 \% \beta$ and $14 \%$ $\delta$ crystallins; the latter present predominantly in the central fibres indicating its embryonic origin.

\section{Acknowledgements}

This article contains a personal account of research on the developmental biology of the chick that began in Geneva, Switzerland, Oak Ridge, Tenn. USA and Lausanne, Switzerland, continued at the University of Poona and completed during the years 1957-2004. Studies on neural induction and competence began in Conrad H. Waddington's laboratory by Leerla Mulherkar in Edinburgh, and then by Jerzy Gallera in Geneva and continued by our group in Poona. The work on cell population regulation during early development in the chick embryo was initiated at the Swiss Institute of Exptl. Cancer Research, Lausanne, and further continued in the laboratory in Poona (Pune) in the context of the process of neural induction, neural competence and teratogenesis. My work on lens development and differentiation, mentored by Tuneo Yamada and Fred Bollum during 1967-1973, showed that terminally differentiating, lens fibre cells exhibit programmed cell death that involves loss of DNA due to strand breaks in situ. Analyses of cell population growth in the developing lens, started at Lausanne and completed in Poona, have shown that the rate of cell population growth in epithelial cells regulates the transfer to non-dividing fibre compartment and the subsequent nuclear loss by programmed cell death. I am indebted to Dr. Jerzy Gallera and Prof. Tuneo Yamada, Prof. Frederick J. Bollum, Prof. Jesse. E. Sisken, Prof. Ram Uppuluri, Prof. Klaus Scherrer, Prof. Leela Mulherkar, Dr. Jane Setlow Dr. R.B. Setlow, Dr. Richard Kimball, Dr. Ronald Hart, Dr. Adolf Graessman, Dr. KKG. Menon, Prof. M.R. Bhide, and my colleague Dr. Gerard Nicolet, Geneva, for mentoring me. I thank my M.Sc./M.Phil. and Ph.D. students, post docs and Dr. M.V. Joshi for their dreams and unstinted efforts for keeping me on my toes to bring Science to the forefront and research to fruition. My thanks to Drs. Yves Courtois and Jean Jacques Lawrence from France, Georges Spohr and Prof. Cecile Leuchtenberger from Switzerland, Prof. Tokindo Okada and Prof. M. Asashima from Japan, Prof. Sharmila Basu-Modak, and my friends from all over the world, writers, artists, entrepreneurs and scientists of all cultures and creeds, lovers of a table brimming with culinary delights and good wine, that keep me kicking still.

I am also grateful for the valuable support from the Swiss Federal Government, University of Geneva, U.S. Atomic Energy Commission, Oak Ridge National laboratory, N.I.H.-USA, Swiss National Science Foundation, Swiss Institute for Experimental Cancer Research (now, L' Ecole Polytechnique Fédérale, Lausanne), INSERM-France, Centre for Nuclear Energy - Grenoble, France, University of Poona, India, BRNS-Department of Atomic Energy, India, Department of Science and Technology, India, CSIR-India, UGCIndia, DBT-India, AMBO-Japan. I also thankUICC (WHO) for a visiting Fellowship to Japan.

\section{References}

APPLEBY, D.W. AND MODAK, S.P. (1977). DNA degradation in terminally differentiating lens fibre cells from chick embryos. Proc. Natl. Acad. Sci. USA 74: 5579-5583.

BAGCHI, M., MAISEL, H. AND ELLIS, M. (1982). Protein synthesis in organ cultured chick lens. Exp. Eye Res. 35: 325-329.

BHARGAVA, SAND MODAK, S.P. (2002). Expression of nervce growth factor during the development of nervous system in early chick embryo. Dev. Brain Res. 136: 43-49.

Brahma, S. K. and Van der Starre, W.J. (1976) Studies on biosynthesis of soluble lens crystalline antigens in chick by isoelectric focussing in thin layer polyacrylamide gels. Exp. Cell Res. 97: 175-183

CHIPLONKAR, J.M. AND GOEL S.C. (1975). Effects of gamma rays on the developing embryos of Calotes versicolor. Experientia 31: 1213-1215.

COHEN, M.M. AND NADLER, H.L. (1983). Abnormalities of the sex chromosomes. In Nelson's Text Book of paediatrics. 12tjh (Eds. R.E. Behrman and V.C. Vaughan). W.B Saunders Co. Philadelphia, pp. 324-325.

DE ROBERTIS, E.M. FAINSOD, A. GOUT, L.K. ANDF STREINBEISSER, H. (1994). Evolution of vertebrate gastrulation. Dev. Suppl. 117-124.

DESHMUKH, S., SONAWANE, M. AND MOPDAK, S.P. (2001). The neural inductive response of competent chick ectoblast decreases away from the host axis and correlates with an increased proliferative activity. Int. J. Dev. Biol. 45: 759- 766.

DESHMUKH-BARVE, S., JOSHI-BANKA, D. and MODAK, S.P. (2003). The proliferative state, graft-site and contact-time of competent chick ectoblast determine the quality and quantity of neural inductgion by Hensen's node. Int. J. Dev. Biol. 47: 355-361.

DIWAN, B.A. (1966). A study of the effect of colchicine on the process of morphogenesis and induction in chick embryos. J. Embryol. Exp. Morph. 16: 245-267.

DIWAN, B.A. and MULHERKAR, L. (1980). Effect of N-ethylurethane on morphogenesis of chick embryos cultivated in vitro. Indian J. Exp Biol. 12: 182-183.

DOWNIE, J.R. (1976). The mechanism of chick blastoderm expansion. J. Embryol. Exp. Morph. 35, 559-575.

EMANUELSSON, H. (1965). Cell multiplication in the chick blastoderm up to the time of laying. Exp. Cell Res. 39: 386-399.

GALLERA, J. (1964). Excision et transplantation des differentes regions de la ligne primitive chez le poulet. Bull de l'Assoc. d'Anat. 49: 632-639.

GALLERA, J. (1970). L'action del'actinomycine D sur le pouvoir inducteur de noeud de Hensen et la competence nmeurogene de l'ectoblaste de poulet. J. Embryol. Exp. Morph. 23: 473-489.

GALLERA, J. and IVANOV, I. (1964). La compétence neurogène du feuillet externe du blastoderme de poulet en function du facteur temps. J. Embryol. Exp. Morph. 
12: 693-711.

GALLERA, J. (1971). Primary Embryonic Induction. Adv. Morphogenesis 9: 149-180.

Gallera, J. and Nicolet, G. Quelques commentaires sur les méthods de culture in vitro de jeunes blastoderme de poulet. Experientia. 17, 134-135 (1960).

GALLERA, J. and NICOLET, G. (1961). Le pouvoir inducteur de l'endoblaste présomptif contenue dans la ligne primitive jeune de poulet. J. Embryol. Exp. Morph. 21: 105-118.

GEHRING, W. (1985). The Homeo Box. A key to the understanding of development? Cell 40: 3-5.

GHATPANDE, S.K. (1992). Role of Cell population growth in normal and abnormal morphogenesis. Ph.D. Thesis, University of Poona, pp. 1-91.

GHATPANDE, S.K., GUTTIKAR, G., PARANJAPE, S. MULHERKAR, L and MODAK, S.P. (1990). Cell population growth in chick blastoderms cultivated in vitro. Ind. J. Exp. Biol. 28: 526-530.

GHATPANDE, S.K. MULHERKAR, L and MODAK, S.P. (1991). Cell population growth and area expansion in early chick embryos during normal and abnormal morphogenesis in vitro. Dev. Growth Differ. 33: 605-615.

GHATPANDE, S.K., VAIDYA, P.K., MULHERKAR, L. and MODAK, S.P. (1993). Lithium chloride and Trypan blue induce abnormal morphogenesis by suppressing cell population growth. Dev. Growth Differ. 35: 409-419.

GOEL, C., (1987). Expression of Neuroblast sequences during chicken development. M.Phil. Dissertation, University of Poona, Pune India, pp 1-60.

Gokhale, V. and Mulherkar, L. (1980). Studies on the mechanism of action of urethane in the chick embryos cultured in vitro. J. Anim. Morph. Physiol. 53: 158-159.

GUTTIKAR, G., PATIL, S.S., GOEL, C., RANE, R.K., JOSHI, M.V., MULHERKAR, L. and MODAK, S.P. (1993) Multiple neural inductions in area opaca by grafts of the Hensen's node do not retard host chick embryo development. Ind. J. Exp. Biol. 31: 803-807.

HAMBURGER, V. AND HAMILTON, H.L. (1952). A series of normal stages in the development of the chick embryo. J. Morph. 88: 49-92.

HARBISON, R.D. (1980). Teratogens, in Casarett and Doull's Toxicoloy, The basic science of poisons (Eds. C.D. Klassen, $2^{\text {nd }}$ ed), McMillian Publ., New York), pp. 158-175.

HOLTFRETER, J. (1938). Differnziereungspotenzen isolierter teille der Urodelen gastrula. Arch. Entwe. Mech. Org. 138: 522

JOSHI-BANKA, D. DESHMUKH, S. and MODAK, S.P. (2001). The neural inductive signal is tgransferred to ectoblast in- $2 \mathrm{hr}$ but a continued contact with mesoblast for $2-3 \mathrm{~h}$ is essential for neutralization in the chick area pellucida. Int. J. Dev. Biol. 45: 767-770.

JOSHI-BANKA, D., PARANJAPE, S., GHASKADBI, S. and MODAK, S.P. (2002). Postnodal mesoblast caudalizes the host axis and inhibits cell population growth and induces new primitive streaks in chick embryos. Dev. Growth Diff. 44: 169-180.

JOSHI, M.V., SHAH, V.B. and MODAK, S.P. (1991). Isonicotinic Acid hydrazide inhibits cell population growth during teratogenesis of chick embryo. Ind. J. Exp. Biol. 29: 12-15.

JOSHI S.S. and JOSHI, M.V. (1981). Effect of Aflatoxin B1 on early embryonic stages of the chick Gallus domesticus cultured in vitro. Ind. J. Exp. Biol. 19: 528-531.

KATDARE, S.M. and MULHERKAR, L. (1972) Alleviation of toxicity of Actinomycine $\mathrm{D}$ by uridine and Thymidine on the morphogenesis of chick embryos cultivated in vitro. Experientia 28: 690-692.

KELLER,R., DAVIDSON, L., EDLUND, A., ELUL, T., EZIN, M. SHOOK, D. and SKOGLUND, P. (2000). Mechanisms of convergence and extensi on by cell intercalation. Phil. Trans. Royal Soc. B Biol. Sci. S 355: 897-922.

KISPERT, A. ORTNER, J. COOKE J. and HERRMANN, B.G. (1995). The chick brachyuri gene developmental expression pattern and response to axial induction by localised activing. Dev. Biol., 168: 406-415.

Lakshmi, M.S. (1962). The effect of chloroacetophenone on chick embryos cultured in vitro. J. Embryol. Exp. Morph. 10: 373-382.

Leikola, A. (1976). Hensen's Node: 'The Organizer' of the amniote embryo. Experientia 32: 269-277.

LEMAIRE, L. and KESSEL, M. (1997). Gastrulation and homeobox genes in chick embryos. Mech. Develop. 67: 3-16.

MATHUR J.K. and GOEL S.C. (1976). Effects of trypan blue on the development of the garden lizard, Calotes versicolor. Teratology 14: 99-109.
MCBRIDE, W.G. (1977). Thalidomide embryopathy. Teratology 16: 79-82.

MCMASTER, G. and MODAK, S.P. (1977). Cellular and biochemical parameters of growth of chick blastoderm during early morphogenesis. Differentiation 8: 145-152.

MODAK, S.P. (1965). Sur l'origine de l'hypoblaste chez les oiseaux. Experientia 21: $273-275$

MODAK, S.P. (1966). Analyse expérimentale de l'origine de l'endoblaste embryonnaire chez les oiseaux. Rev. Suisse Zool. 73: 877-908.

MODAK. S.P. (2003). Chick-embryo culture techniques employed at Karnatakuniversity in Dharwad, India, for studying cellular and molecular aspects of morphogenesis. Int. J. Dev. Biol. 47: 165-170.

MODAK, S.P. and BEARD, P. (1980). Analysis of DNA double and single strand breaks by two dimensional electrophoresis: action of micrococcal nuclease on chromatin and DNA degradation in vivo of lens fibre chromatin. Nucleic Acid. Res 8: 2665-2678.

MODAK, S. P and BOLLUM, F.J. (1970). Terminal lens cell Differentiation. III. Initiator activity of DNA during nuclear degeneration. Exp. Cell Res. Exp. Cell Res. 62: 421-432

MODAK, S.P. and BOLLUM, F.J. (1972). Detection and measurement of single strand breakd in nuclear DNA in fixed lens sections. Exp. Cell Res. 75: 307-313.

MODAK, S.P. and PERDUE, S.W. (1970) Terminal Cell Differentiation. I. Histological and microspectro-photometric analyses of nuclear degeneration. Exp. Cell Res. 59: 43-45.

MODAK, S.P., VON BORSTEL, R.C. and BOLLUM, F.J. (1969). Terminal Lens Cell differentiation. II. Template activity of DNA during nuclear degeneration. Exp. Cell Res. 56: 105-113.

MODAK, S.P. and PERSONS, B.G. (1971). RNA synthesis during lens cell differentiation. Exp. Cell Res. 473-476.

MODAK, S. P. and UNGER-ULLMANN, C. (1980). Control of Genome Integrity in Differentiating and Ageing cells. In Differentiation and Neoplasia (eds. R.G. McKinnel, M.A. DiBernardino, M. Blumenfeld and R.D. Bergad), Springer Verlag, Berlin, Heidelberg, New York pp. 178-190.

MODAK, S.P., GHATPANDE, S.K., RANE, R.S. and MULHERKAR, L. (1993). Caudalization by retinoic acid is correlated with inhibition of cell population growth and expansion of chick blastoderms cultured in vitro. Int. J. Dev. Biol. 37: 601-607.

MODAK, S.P. MORRIS, G. and YAMADA, T. (1968). DNA synthesis and mitotic activity during early development of chick lens. Dev. Biol. 17: 544-561.

MODAK,S.P., LEVER,W.E., THERWATH, A. and UPPULURI, V.R.R.,(1973). Estimation of proportion of cell nuclei in tissue sections falling within tritium autoradiographic range. Exp. Cell Res. 76: 73780.

MODAK, S. P., UPPULURI, V.R.R., APPLEBY, D.W., THERWATH, A.M. and LEVER W.E. GROWTH (1976). Kinetics of epithelial and fibre cells in developing chick lens. In Biology of lens Epithelial cells. INSERM publ. Paris. France, Vol. 60, pp 105-112.

Mac Auley, A., Werb. Z. and Mirkes, P.E. (1993). Characterisation of unusually rapid cell cycles during rat gastrulation. Development 117: 873-883.

MULHERKAR, L. (1960). The effects of Trypan Blue on chick embryos cultivated in vitro. J. Embryol. Exp. Morph. 8: 1-5.

Mulherkar, L., Joshi, S.S., Diwan, B.A. Joshi, P.N. et al., (1967). A study of the mode of action ofchloramphenicol on the chick embryos. J. Embryol. Exp. Morph. 17: 263-266.

MULHERKAR, L. (1958). Induction by regions lateral to the streak in the chick embryo. J. Embryol. Exp. Morph 6: 1-14.

MULHERKAR, L. JOSHI, P.N. and DIWAN, B.A. (1967). A study of mode of action of chloramphenicol on the chick morphogenesis. Experientia. 23: 1-8.

MULHERKAR, L and JOSHI, P.N. (1969). Further observations on the mode of action of chloramphenicol on the chick morphogenesis. Experientia 25: 1303-1304

NIEUWKOOP, P.D. (1952). Activation and organization of the central nervous system in amphibians: Synthesis of a new working hypothesis. J. Exp. Zool. 120: 83-10.

NEW, D.A.T. (1955). A technique for cultivation of chick embryo in vitro. J. Embryol. Exp. Morph. 3: 326-331.

NEW, D.A.T. (1959). The adhesive properties and expansion of the chick blastoderm J. Embryol. Exp. Morph. 7: 146-164

NICOLET, G. (1965). Action de chlorure de Lithium sur la morphogenese du jeune embryon de poulet. Acta Embryol. Morphol. Exp. 8: 32-35.

NICOLET, G. (1971). Analyse autoradiographique de la localisation des differentes 
ebauches presomptives dal la ligne primitive de l'embryon de poulet. J. Embryol. Exp. Morph. 23: 79108.

NICOLET, G. (1971). Avian Gastrulation. Adv. Morphogen. 9: 231-261.

OLSZANSKA, B. and LASSOTA, Z. (1980). Simple in vitro system for molecular study of early embryonic development in the quail. Brit Poultry Sci. 21: 395-403.

PAL, J.K. and MODAK, S.P. (1984). Immunochemical characterization and quantitative distribution of crystallins in the epithelium and differentiating fibre cell populations of chick embryonic lens. Exp. Eye Res. 39: 415-434.

PERA, E., STEIN, S. and KESSEL, M. (1999). Ectodermal patterning in the avian embrtyo. Development 124, 4253-4162.

PERSONS, B.J. and MODAK, S.P. (1970). The pattern of DNA synthesis in the lens epithelium and the annular pad during development and growth of ther chick lens. Exp. Eye Res. 9: 144-151.

PIATIGORSKY, J. (1980). Lens Differentiation in vertebrates. Differentiation. 19: 134-153.

RAMAKRISHNAN, R. (1988). Developmental programme of gene expression and characterization of galactosyl-transferase messengerRNA. Ph.D. thesis, University of Poona, Pune, India. pp.1-268.

RAO, K.V. and CHAUHAN, S.P.S. (1971). Teratogenic effects of rotenone on early developmental stages of chick embryos in vitro. Teratology 4: 191-198.

ROGULJA, D. and IRVINE, K.D. (2005). Regulation of cell proliferation by a morphogen gradient. Cell 123, 449-461.

ROMANOFF, A. (Ed.) (1972). Pathogenesis of the avian embryo. Wiley-Interscience, New York, London, Sydney, Toronto.

ROSENQUIST, G.C. (1966). A radioautographic study of labelled grafts in the chick blastoderm. Development from primitive-streak stage to stage 12. Contrib. Embryol. Carnegie Inst. Washington 262: 73-110.

SAUNDERS, J.W. JR. and FALLON, J.F. (1966) Cell death in morphogenesis, In Major problems in developmental biology. (Ed. M. Locke) Academic Press, New York and London, pp. 289-316.

SHERBET, G. V. (1963). Studies on transplantations of amphibian anterior pituitary into chick embryo. Analysis of induction capacity of differential solubility and precipitation method. J. Embryol. Exp. Morph. 2: 227-237.

SOLOMAN, J.B. (1957). Increase of deoxyribonucleic acid and cell number during morphogenesis of the early chick embryo. Biochim. Biophys. Acta 33: 23-27.

SONAWANE, M. S. (2000). Cell population growth kinetics during development growth and differentiation. Ph.D. Thesis, University of Poona, Pune, India, pp. 1-81. .

SONAWANE, M.S., THERWATH, A. and MODAK, S.P. (1999). Cell population growth during the formation of the chick eye lens. Curr. Sci. India 77: 289-229.

SPRATT, N. T. Jr. (1966). Some problems and principles of development. Am. Zoologist. 6: 9-19.
STERN, C. D. (2002). Initiation and initial patterning of the nervous system-the chick embryo enters the scene. Curr.Opinion Ge. Develop. 12, 447-451.

STERN, C.D. (1979). A re-examination of mitotic activity in the early chick embryo. Acta Embryol. 156: 319-329.

STOCKDALE, F.E. and HOLTZER, H. (1961). DNA synthesis and myogenesis. Exp. Cell Res. 24: 508520.

STOREY, K.G., CROSSLEY, J.M., DE ROBERTIS, E.M., MORRIS, W.E. and STERN, C.D. (1992). Neural induction and regionalisation in the chick embryo. Development.114: 729-741.

TELANG, N. T, and MULHERKAR, L. (1974). In vitro studies on the effects of hydrazine on the morphogenesis of chick embryos and the mechanism of its action. Oncology 30: 529541.

UNGER-ULLMANN, C. and MODAK, S.P. (1979). Characterization of histones lens epithelium, lens fibres, liver, brain and erythrocytes from chick embryo. Differentiation.12, 136-144.

VAKAET, L. (1962). Some more data concerning the formation of the definitive endoblast in the chick embryo. J. Embryol. Exp. Morph. 10: 38-57.

WADDINGTON, C.H. (1932). Experiments on the development of chick and duck embryos, cultivated in vitro. Phil. Trans. London 221: 170-230.

WAHEED, M.A. and MULHERKAR, L. (1967). Studies on induction by substances containing sulphydryl groups in post-nodal pieces of chick blastoderm. J. Embryol. Exp. Morph. 17: 161-169.

Woodside, G.L. (1937). The influence of host age on induction in the chick blastoderm J. Exp. Zool. 75: 259-281.

WYLIE, C.C. (1972). The appearance and quantitation of cytoplasmic ribonucleic acid in the early chick embryo. J. Embryol. Exp. Morph. 28: 367-384.

YAMADA, T. (1950). Dorsalization of the ventral marginal zone of the Triturus gastrula I. Ammonia treatment of the medioventral marginal zone. Biol. Bull. 98: 98-121.

YAMADA, T. (1977). Control mechanisms In cell-type conversion in newt lens regeneration. In Monographs in Dev. Biol. 13. (Ed. A. Wolsky) pp. 1-126.

YAMADA, T. (1990). Regulation in the induction of the organized neural system in amphibian embryos. Development 110: 653-659.

YAMADA, T. (1994). Caudalization by the amphibian organizer: Brachyuri, convergent extension and retinoic acid. Development 120: 3051-3062.

YAMADA, T. (1995) Anterior-posterior specification in amphibian embryogenesis: the regulative roles of positive and negative controls of mitogenesis. Dev. Growth Differ. 37: 365-372.

YAMADA T. and MODAK, S.P. (1998). Genetic evidence for posterior specification by convergent extension in the Xenopus embryo. Dev. Growth Differ. 49: 125-132.

ZWAAN, J. and IKEDA, A. (1968). Macromolecular events during differentiation of the chicken eye lens. Exp Eye Res. 7: 301-311. 


\section{Further Related Reading, published previously in the Int. J. Dev. Biol.}

Development and programed cell death in the mammalian eye

Elena Vecino and Arantxa Acera

Int. J. Dev. Biol. (2015) 59: 63-71

https://doi.org/10.1387/ijdb.150070ev

Pitx3 directly regulates Foxe3 during early lens development

Nafees Ahmad, Muhammad Aslam, Doris Muenster, Marion Horsch, Muhammad A. Khan, Peter Carlsson, Johannes Beckers and Jochen Graw Int. J. Dev. Biol. (2013) 57: 741-751

https://doi.org/10.1387/ijdb.130193jg

\section{Congenital hereditary cataracts}

Jochen Graw

Int. J. Dev. Biol. (2004) 48: 1031-1044

http://www.intjdevbiol.com/web/paper/041854jg

\section{Development of lens sutures}

Jer R. Kuszak, Rebecca K. Zoltoski and Clifford E. Tiedemann

Int. J. Dev. Biol. (2004) 48: 889-902

http://www.intjdevbiol.com/web/paper/041880jk

Activated Ras induces lens epithelial cell hyperplasia but not premature differentiation Lixing W. Reneker, Leike Xie, Li Xu, Venkatesh Govindarajan and Paul A. Overbeek Int. J. Dev. Biol. (2004) 48: 879-888

http://www.intjdevbiol.com/web/paper/041889lr

Expression of Frizzleds and secreted frizzled-related proteins (Sfrps) during mammalian lens development

Yongjuan Chen, Richard J.W. Stump, Frank J. Lovicu and John W. McAvoy

Int. J. Dev. Biol. (2004) 48: 867-877

http://www.intjdevbiol.com/web/paper/041882yc

Regulation of cell adhesion and migration in lens development

Peggy S. Zelenka

Int. J. Dev. Biol. (2004) 48: 857-865

http://www.intjdevbiol.com/web/paper/041871pz
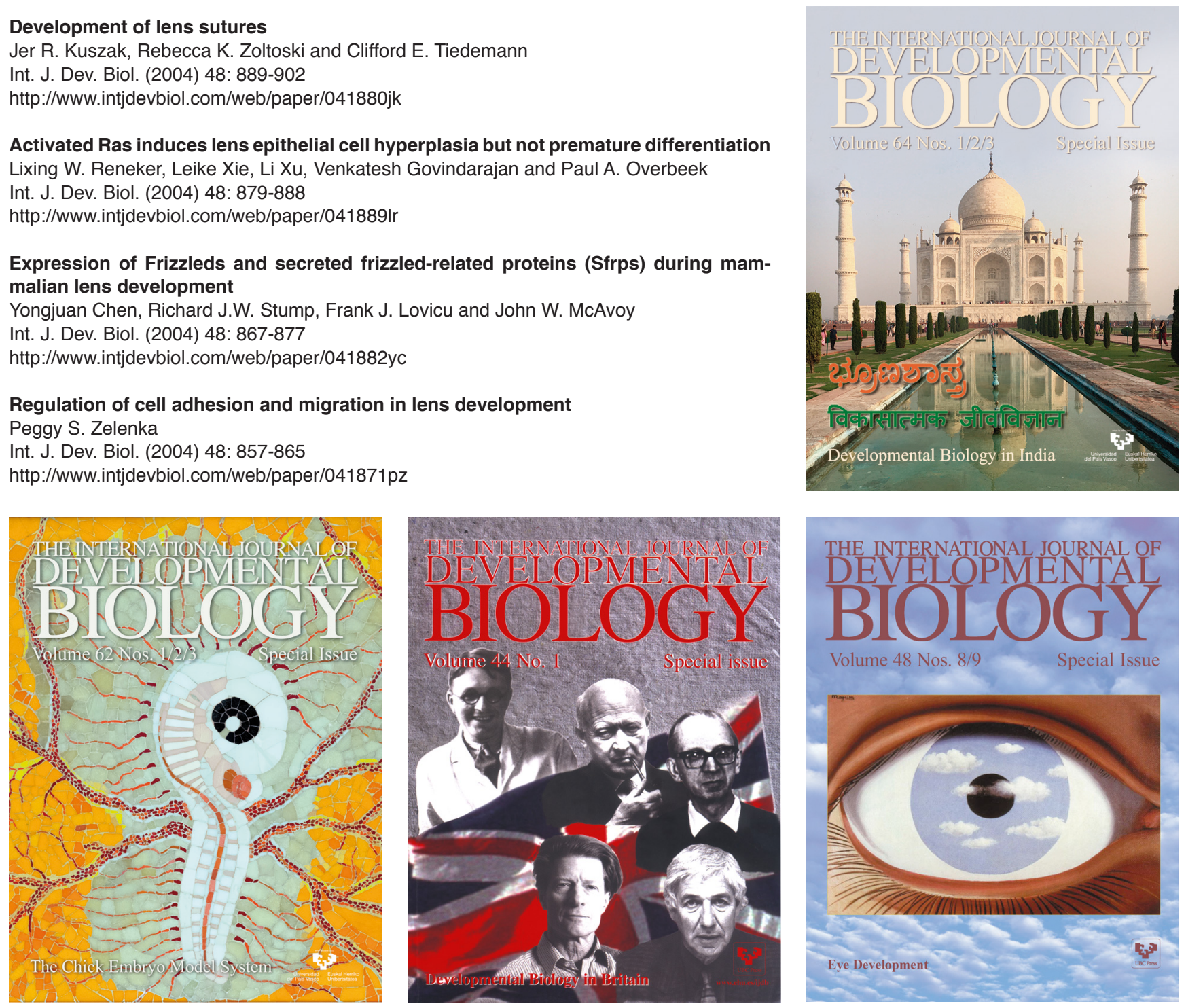